\title{
Hypoglycemic and hypolipidimic effect of naringin in diabetic male rats
}

\author{
M. J. J. Al-Kurdy \\ Technical Institute -diwaniya
}

\begin{abstract}
The current study aimed to determine the potency of aqueous extract of grape fruit (Naringin) in lowering blood glucose and lipid profile in streptozotocin induced diabetic male rats (by single injection of Streptozotocin at the dose of $60 \mathrm{mg} / \mathrm{kg}$ of the body weight). Naringin was extracted from grapefruit albedo (white inner Pell) by using aqueous hydrolysis, then it was identified on Thin Layer Chromatography (TLC).The results of thin layer chromatography have showed that $\mathrm{Rf}$ values was 0.75 in aqueous extract compared with Rf standard naringin (0.76). Twenty four adult male rats were randomly assigned to three equal groups treated for 30 days as follows: Intact control (C) , Diabetic Control (D.M.), treated diabetic rats $(\mathrm{T})$ received $(80 \mathrm{mg} / \mathrm{kg}$ B.W.) of flavonoids (naringin). Blood sample were obtained befor and after 10,20 and 30 days from treatment. The results showed significant decrease in body weight, blood glucose, cholesterol, and triglyceride in T group. These results showed that naringin has potential hypoglycemic and hypolipidemic effect in streptozotocin induced diabetic rats.
\end{abstract}

Key words: grape fruit, naringin, diabetes.

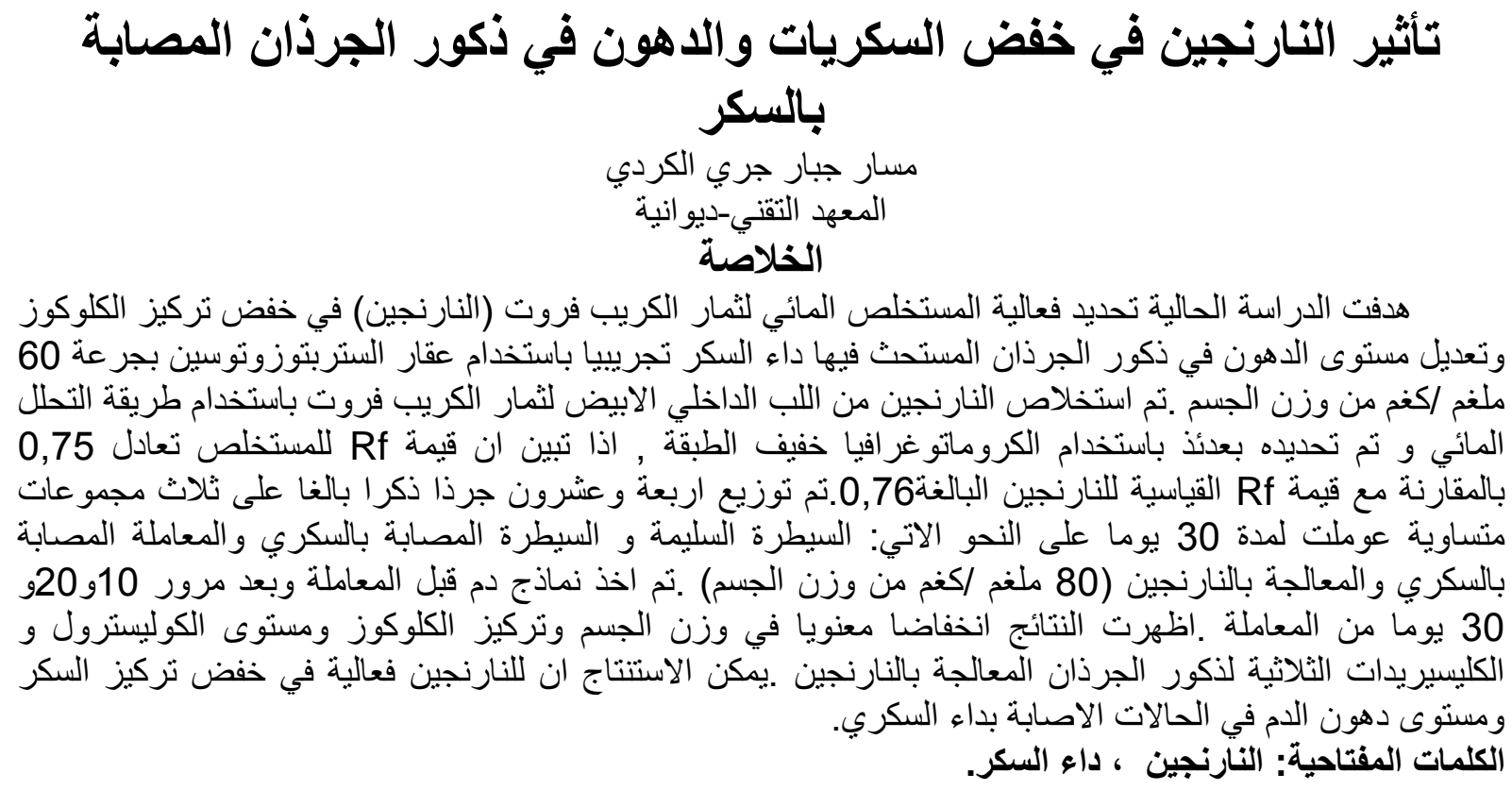

\section{Introduction}

Diabetes mellitus is one of the major health problems in both developed and underdeveloped countries. Diabetes mellitus, a pervasive and multifactorial metabolic syndrome, is characterized by imperfection in insulin secretion and insulin receptor or post receptor events with derangement in carbohydrate, protein and lipid metabolism, and results in chronic hyperglycemia [1].
Hyperglycemia and hyperlipidemia, as the most common features of diabetes mellitus, contribute to the development of microvascular and macrovascularm complications of diabetes, which cause the morbidity and mortality of diabetes [2]. In addition, hyperglycemia in diabetic patients is associated with alteration in glucose and lipid metabolism and modification in liver enzyme levels [3]. Diabetes mellitus is 
recognized as a major risk factor for cardiovascular diseases (CVD) such as atherosclerosis, heart attack, stroke, etc. About $75 \%$ of deaths among men with diabetes and $57 \%$ among women with diabetes are attributable to CVD [4]. Now a days, the agents used as the main means for diabetes treatment are synthetic drugs and insulin. However, these drugs usually come with considerable side effects, such as hypoglycemia, drug resistance, dropsy, and weight gain. In contrast, hundreds of traditional folk medicines have demonstrated potential for the treatment of diabetes with less tolerability and side effects. Thus, there is an increasing need to search for more natural anti diabetic agents from the traditional medicine. [5].Flavonoids are a group of naturally occurring compounds ubiquitous in the plant kingdom and known to have strong antioxidant effects. They are widely distributed in foods of plant origin such as vegetables, fruits, tea and wine. Naringin (4',5,7-trihydroxy flavonone 7 rhamnoglucoside) is the predominant flavonone found in grape fruit and related citrus species [6].Currently, there is much interest in the usefulness of citrus fruits because of their intake appears to be associated with reduced risk of certain chronic diseases and increased survival [7]. Naringin is responsible for the characteristic sour flavor of the fruits [8]. Among the naturally occurring flavonoids, naringin has been empirically proven to have no side effects, as humans have been ingesting grapes and citrus fruits for a long time [9]. The role of recently received considerable attention as dietary antioxidant. Naringin exhibits various pharmacological and therapeutic properties: antimicrobial, antimutagenic, anticancer , anti-inflammatory , cholesterol lowering, free radical scavenging and antioxidant effects [10].

\section{Materials and methods}

\section{Preparation of aqueous extract (naringin)}

Naringin was extracted from grapefruit albedo (white inner Pell) using the method of Ikan [11] was used as anti-diabetic plants. Chromatography of dried flavonoid fraction was carried out on a silica gel type $G$ aluminum plate $(20 * 20 \mathrm{~cm})$ at a thickness of $0.25 \mathrm{~mm}$ supplied from Fluka company.

\section{Induction of diabetes in rats :}

twenty four adult albino male rats weighting 175-225 grams (75-90 days old) were used for this investigation. The animals were injected by single dose of streptozotocin $(60 \mathrm{mg} / \mathrm{kg}$ of the body weight intrapertonial). Streptozotocin induces diabetes within( 3-5) days by destroying the beta cells [12].

\section{Experimental Design}

twenty four adult Albino male rats were randomly assigned to three groups (8 rats/ group) and were treated daily for 30 days as follows:1.C: intact rats received only drinking water.2.D.M: Diabetic Control rats received only distilled water.3.T: diabetic rats: received $(80 \mathrm{mg} / \mathrm{kg} \mathrm{B.W.)}$ of flavonoids (naringin) extracted from grapefruit [13],by oral administration with gavage needle.

\section{Blood Sampling}

Fasting blood (for 8-12 hrs.) samples were obtained at 10 days interval after injection of Streptozotocin. Blood was drawn by cardiac puncture technique from anesthetized rats [intramuscular injection of Ketamine ( $90 \mathrm{mg} / \mathrm{Kg} \mathrm{B.W.)} \mathrm{and} \mathrm{xylazine} \mathrm{(40}$ $\mathrm{mg} / \mathrm{kg}$ B.W.)].Blood samples were kept in tubes, and centrifuged at $3000 \mathrm{rpm}$ for 15 minutes, and then serum samples were collected and frozen at $-20^{\circ} \mathrm{C}$ until analysis.

\section{Blood glucose measurement:}

Blood glucose was measured by enzyme colorimetric method [14].GLUCOSE MR® Kit was used for this purpose.

\section{Determination of Serum Total Cholesterol (TC) Concentration (mg/dl)}

Serum total cholesterol TC concentration was enzymatically measured using enzymatic assay kit, based on the fact that steroids produce an intense color with oxidizing acids. Cholesterol oxidized by the action of cholesterol oxidase and the liberated $\mathrm{H}_{2} \mathrm{O}_{2}$ reacts with phenol and 4amion antipyrine in a peroxide catalyzed reaction to yield aquinoneminedye, which has a maximal absorbency at $500 \mathrm{~nm}$. The intensity of color produced is directly proportional to the concentration of cholesterol in serum [15]. 
Determination of Serum Triacylglycerol (TG) Concentration (mg/dl)

Enzymatic estimation of serum TG concentration was carried out using Triacylglycerol kit, based on the measurement of glycerol liberated from hydrolysis of TG enzymatically (by lipase enzymes).

\section{Statistical Analysis}

Statistical analysis of data was performed on the basis of one-Way Analysis of Variance (ANOVA) using a significant level of $(\mathrm{P}<0.05)$. Specific group differences were determined using least significant differences (LSD) as described by [16].

\section{Results}

\section{Thin Layer Chromatography}

Results of thin layer chromatography, performed on grape fruit extract, showed that naringin $\mathrm{Rf}$ was 0.75 compared with standard $\operatorname{Rf}(0.76)$ (Figure 1).

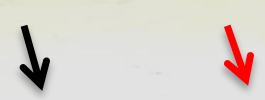

Figure (1): showed naringin $R f(0.75)$ compared with standard Rf (0.76). Red arrow represent naringin, Black arrow represent standard.

\section{Body weight:}

Result of body weight (g)clarified in table (1) show significant differences $(p<0.05)$ between diabetic groups(D.M. and $\mathrm{T})$ and control group $(\mathrm{C})$ starting on first week and continue throughout the following weeks of the experimental. The total cumulative body weight gain, at the end of the experimental period recorded significant decrease $(p<0.05)$ in diabetic groups compared with that of control group. At the same time, body weight gain of diabetic untreated group recorded significantly $(\mathrm{p}<0.05)$ higher gain compared with diabetic treated group.
Table(1):Effect of aqueous extraction of grape fruit (Naringin) on body weight (g) in mature male rate.

\begin{tabular}{|c|c|c|c|}
\hline $\begin{array}{l}\text { Groups } \\
\text { Days }\end{array}$ & $\mathrm{C}$ & D.M. & $\mathrm{T}$ \\
\hline $\begin{array}{l}\text { Before } \\
\text { treatment }\end{array}$ & $\begin{array}{l}132.0 \pm \\
0.60 \mathrm{~A}\end{array}$ & $\begin{array}{l}131.0 \pm 0.74 \\
\mathrm{~A}\end{array}$ & $\begin{array}{l}134.6 \pm 0.80 \\
\text { A }\end{array}$ \\
\hline $\begin{array}{l}\text { First } \\
\text { week }\end{array}$ & $\begin{array}{l}133.0 \pm 0.90 \\
\text { A }\end{array}$ & $\begin{array}{l}115.0 \pm 6.08 \\
\text { B }\end{array}$ & $\begin{array}{l}108.2 \pm 1.28 \\
\text { B }\end{array}$ \\
\hline $\begin{array}{l}\text { Second } \\
\text { week }\end{array}$ & $\begin{array}{l}142.6 \pm \\
2.40 \mathrm{~A}\end{array}$ & $\begin{array}{l}117.0 \pm \\
6.07 \mathrm{~B}\end{array}$ & $\begin{array}{l}101.6 \pm 0.50 \\
\text { C }\end{array}$ \\
\hline $\begin{array}{l}\text { Third } \\
\text { week }\end{array}$ & $\begin{array}{l}154.2 \pm 3.43 \\
\text { A }\end{array}$ & $\begin{array}{l}108.2 \pm 3.56 \\
\text { B }\end{array}$ & $\begin{array}{l}100.0 \pm 1.58 \\
\text { B }\end{array}$ \\
\hline $\begin{array}{l}\text { Four } \\
\text { week }\end{array}$ & $\begin{array}{l}162.1 \pm 4.21 \\
\text { A }\end{array}$ & $\begin{array}{l}102.6 \pm 1.88 \\
\text { B }\end{array}$ & $\begin{array}{l}84.4 \pm 1.24 \\
\mathrm{C}\end{array}$ \\
\hline
\end{tabular}

Values are expressed as mean $\pm \mathrm{SE}, \mathrm{n}=8$ each group. $\mathrm{C}$ : control group: drenched with distal water daily for 4 weeks. D.M.: Diabetic control: drenched with distal water daily for 4weeks. T: diabetic rats drenched aqueous extraction of grapefruit (naringin) $(80 \mathrm{mg} / \mathrm{kg}$ b.w.) daily for 4 weeks. Capital letters denote differences between groups, $\mathrm{P}<0.05$ vs. control.

\section{Blood glucose concentrations:}

Result of blood glucose concentrations showed significant increase $(\mathrm{p}<0.05)$ in DM, and $\mathrm{T}$ group showed significant decrease $(p<0.05)$ in comparison with DM group, but still significantly higher $(\mathrm{p}<0.05)$ than control (table 2).

Table (2): Blood Glucose Levels in the Control and diabetic groups

\begin{tabular}{|c|c|c|c|}
\hline $\begin{array}{l}\text { Groups } \\
\text { Days }\end{array}$ & $\mathrm{C}$ & D.M. & $\mathrm{T}$ \\
\hline 10 & $\begin{array}{l}118.8 \pm 14 . \\
27 \mathrm{C}\end{array}$ & $\begin{array}{l}423.6 \pm 24 . \\
84 \mathrm{~B}\end{array}$ & $\begin{array}{l}336.6 \pm 146 . \\
14 \mathrm{~A}\end{array}$ \\
\hline 20 & $\begin{array}{l}114.7 \pm 5.2 \\
3 \mathrm{C}\end{array}$ & $\begin{array}{l}357.6 \pm 43 . \\
46 \mathrm{~B}\end{array}$ & $\begin{array}{l}385.2 \pm 152 . \\
93 \mathrm{~A}\end{array}$ \\
\hline 30 & $\begin{array}{l}120.6 \pm 10 . \\
80 \mathrm{C}\end{array}$ & $\begin{array}{l}533.0 \pm 28 . \\
68 \mathrm{~A}\end{array}$ & $\begin{array}{l}256.6 \pm 119 . \\
19 \mathrm{~B}\end{array}$ \\
\hline
\end{tabular}

Values are expressed as mean $\pm \mathrm{SE}, \mathrm{n}=8$ each group. $\mathrm{C}$ : control group: drenched with distal water daily for 4 weeks. D.M.: Diabetic control: drenched with distal water daily for 4 weeks. T: diabetic rats drenched aqueous extraction of grapefruit (naringin) $(80 \mathrm{mg} / \mathrm{kg}$ b.w.) daily for 4 weeks. Capital letters denote differences between groups, $\mathrm{P}<0.05$ vs. control.

Serum Total Cholesterol

(TC) Concentration (mg/dl)

Result of serum total cholesterol showed no significant different $(\mathrm{P}<0.05)$ at the 10 days of the experimental periods in $\mathrm{T}$ group as compared to the control. Serum TC concentration showed a significant increase $(\mathrm{P}<0.05)$ at the day 20 of the treatment (222.6 \pm 13.60$)$ in D.M. group as compared with control group $(102.1 \pm 4.21)$, while rats received $80 \mathrm{mg} / \mathrm{kg} \quad$ b.w. of naringin 
significantly suppressed $(\mathrm{P}<0.05)$ the elevated TC concentration at days 20 of the experiment(120.6 \pm 5.71) compared with D.M. group (222.6 \pm 13.60$)$. While at 30 day of experimental periods, serum TC concentration recorded lack significant different $(\mathrm{P}<0.05)$ in $\mathrm{T}$ treated group as compared to the control group .As the same time serum TC concentration showed high significant $(\mathrm{P}<0.05)$ in D.M. treated group when compared with control group.

Table (3) serum total cholesterol ( $\mathrm{mg} / \mathrm{dl})$ concentration in the Control and diabetic groups

\begin{tabular}{|c|l|l|l|}
\hline $\begin{array}{r}\text { Group } \\
\text { Days }\end{array}$ & \multicolumn{1}{c|}{$\mathrm{C}$} & \multicolumn{1}{|c|}{ D.M. } & \multicolumn{1}{c|}{$\mathrm{T}$} \\
\hline 10 & $\begin{array}{l}114.6 \pm 14.6 \\
\mathrm{~A}\end{array}$ & $\begin{array}{l}245.4 \pm 23.29 \\
\mathrm{~B}\end{array}$ & $\begin{array}{l}153.8 \pm 21.25 \\
\mathrm{~A}\end{array}$ \\
\hline 20 & $\begin{array}{l}102.1 \pm 4.21 \\
\mathrm{~A}\end{array}$ & $\begin{array}{l}222.6 \pm 13.60 \\
\mathrm{~B}\end{array}$ & $\begin{array}{l}120.6 \pm 5.71 \\
\mathrm{~A}\end{array}$ \\
\hline 30 & $\begin{array}{l}108.6 \pm 4.14 \\
\mathrm{~A}\end{array}$ & $\begin{array}{l}223.0 \pm 16.02 \\
\mathrm{~B}\end{array}$ & $\begin{array}{l}113.8 \pm 3.07 \\
\mathrm{~A}\end{array}$ \\
\hline
\end{tabular}

Values are expressed as mean $\pm \mathrm{SE}, \mathrm{n}=8$ each group. $\mathrm{C}$ : control group: drenched with distal water daily for 4 weeks. D.M.: Diabetic control: drenched with distal water daily for 4weeks. T: diabetic rats drenched aqueous extraction of grapefruit (naringin) $(80 \mathrm{mg} / \mathrm{kg} \quad$ b.w.) daily for 4 weeks Capital letters denote differences between groups, $\mathrm{P}<0.05$ vs. control.

\section{Serum Triacylglycerol (TG) concentration} (mg/dl)

(Table 4) show the serum TG concentration $(\mathrm{mg} / \mathrm{dl})$ of untreated and treated groups.

$\begin{aligned} & \text { Table(4) } \\
& \text { concentration in the Control and diabetic } \\
& \text { groups }\end{aligned}$
\begin{tabular}{|c|c|c|c|}
\hline $\begin{array}{c}\text { Groups } \\
\text { Days }\end{array}$ & $\mathrm{C}$ & $\mathrm{D} . \mathrm{M}$. & $\mathrm{T}$ \\
\hline 10 & $\begin{array}{c}78.8 \pm 3.12 \\
\mathrm{~A}\end{array}$ & $\begin{array}{c}109.8 \pm 6.58 \\
\mathrm{~B}\end{array}$ & $\begin{array}{c}81.4 \pm 3.31 \\
\mathrm{~A}\end{array}$ \\
\hline 20 & $\begin{array}{c}88.6 \pm 4.32 \\
\mathrm{~A}\end{array}$ & $\begin{array}{c}150.0 \pm 5.05 \\
\mathrm{~B}\end{array}$ & $\begin{array}{c}86.6 \pm 4.23 \\
\mathrm{~A}\end{array}$ \\
\hline 30 & $\begin{array}{c}88.8 \pm 3.36 \\
\mathrm{~A}\end{array}$ & $\begin{array}{c}149.6 \pm 4.57 \\
\mathrm{~B}\end{array}$ & $86.8 \pm 3.15 \mathrm{~A}$ \\
\hline
\end{tabular}

Values are expressed as mean $\pm \mathrm{SE}, \mathrm{n}=8$ each group. $\mathrm{C}$ : control group: drenched with distal water daily for 4 weeks. D.M.: Diabetic control: drenched with distal water daily for 4 weeks. T2: diabetic rats drenched aqueous extraction of grapefruit (naringin) $(80 \mathrm{mg} / \mathrm{kg}$ b.w.) daily for 4 weeks. Capital letters denote differences between groups, $\mathrm{P}<0.05$ vs. control.

The results have revealed that there were no significant differences $(\mathrm{P}<0.05)$ in the mean value of serum TG concentration in
T groups when compared with control group during the experimental period. A significant elevation $(\mathrm{P}<0.05)$ in mean value of serum TG concentration was detected at all experimental period in diabetic group (D.M.) comparing to the control group and group which received naringin( $\mathrm{T})$.

\section{Discussion}

All male rats registered weight gain throughout the experimental period, however the gain differ among groups . D.M. group rats registered the lowest gain which may attributed to the oxidative stress due to metabolic disorders associated with diabetes[4]. The increment of blood glucose concentration in diabetic male rats run parallel with the studies $[17,18]$, as administration of STZ causes rapid destruction of pancreatic $\beta$-cells in rats, which led to impaired glucose stimulated insulin release and insulin resistance [19]. Elevation of blood glucose may be attributed to the reduced entry of glucose to peripheral tissues, muscle and adipose tissue [20].In comparison with non-treated diabetic male rats, the present study revealed highly significant decrease in level of blood glucose in $\mathrm{T}$ group. It can be hypothesized that the possible mechanism of naringin antihyperglycemic action could be due to a possible pancreatic secretion of insulin from existing $\beta$-cells, with an intensification of glucose uptake by peripheral tissues or reduced glucose absorption from the gastrointestinal tract [21]. By their ability to scavenge free radicals, naringin [22] prevent STZ-induced oxidative stress and protect $\beta$-cells resulting in increased insulin secretion and decrease in the elevated blood glucose levels [17].The hypoglycemic effect of flavonoids on diabetes may be due to the increase in insulin-receptor binding followed by increasing the signal sequences [23] or the antioxidant of these flavonoids. The oxidative stress usually results in stimulated superoxide dismutase activity and inhibited insulin binding to insulin receptor [24]. The present study revealed potent hypolipidemic effect of diabetic rats in which cholesterol and triglycerides were reduced. These results are in agreement with those of Ismail et 
al.[25] who found the diabetes increased all lipids profile except HDL-C was decreased in rats serum. It can be concluded that naringin was effective in ameliorating complication associated with diabetic mellitus. Thus, citrus flavonoids, such as naringin, can be considered as a therapeutic option for the treatment of diabetic; clinical trials are required to establish the safety of these natural compounds.

\section{References}

1-American Diabetes Association.( 2010).Diagnosis and classification of diabetes mellitus. Diabetes Care .,33:(Suppl 1):S62-S69.

2-Taskinen, M.R.(2002): Diabetic dyslipidemia. Atheroscl Suppl;3:47-51.

3-Jenson, T. and Stender, Deckert, T. (1998). Abnormalities in plasma concentration of lipoprotein and fibrinogen in type 1 (insulin dependent) diabetic patients with increased urinary albumin excretion. Diabetologia.,31:142-146.

4-Moller, D.( 2004). New drug targets for type 2 diabetes and the metabolic syndrome: a review. Nature.,414:821-827.

5-Tahrani, A.A.; Piya, M. K.; Kennedy, A. and Barnett, A.H.( 2010). Glycaemic control in type 2 diabetes: targets and new therapies. Pharmacol Ther., 125:328-361.[IVSL]

6-Jagetia, G.C.and Reddy, T.K. (2002).The grapefruit flavonone naringin protects against the radiationinduced genomic instability in the mice bone marrow: a micronucleus study . Mut Res. ,519: 37-48.

7-Chen, H.; Ward, M.H.and Graubard, B.I. (2002).Dietary patterns and adenocarcinoma of the esophagus and distal stomach. Am J Clin Nutr 75: 137-144.

8-Kim, D.H.; Jung, E.A.; Song, I.S.; Han, J.A.,; Kim, T.H.and Han, M.J. (1998).Intestinal bacterial metabolism of flavonoids and its relation to some biological activities. Arch Pharmacol Res., 21: 17-23.

9-Choe , S.C.; Kim, H.S.; Jeong, T.S. Bok, S.H.and Park, T.B.( 2001). Naringin as an antiatherogenic effect with the inhibition of intracellular adhesion molecule-1 in hypercholesterolemic rabbits. J Cardiovasc Pharmacol., 38: 947-955.

10-Rajadurai, M, Stanely, M. P .( 2006). Preventive effect of naringin on lipid peroxides and antioxidants in isoproterenol-induced cardiotoxicity in Wistar rats: Biochemical and histopathological evidences. Toxicol., 228: 259 268.

11- Ikan, R. (1969). Natural products, Academic press. London, pp. 260-270.

12-Karunanayake, E.H.; Hearse, D. J.and Mellows, G.( 1975). The metabolic fate and elimination of streptozocin. Biochemical Society Transactions., 3: $410-14$
13-Ali, M. M. and Abd El Kader, M.A.(2004). The Influence of Naringin on the Oxidative State of Rats with Streptozotocin-Induced Acute Hyperglycaemia, National Research Center, Biochemistry Department, Division of Genetic Engineering and Biotechnology,pp., 726-733.

14-Tietz, N.W.(1995). Clinical guide to laboratory tests, $3^{\text {rd }}$ Edition. W.B. Saunders Co. philadelphia, PA.

15-Ellefson, R. and Garaway, W. (1976). Lipids and lipoproteins. In: Fundamentals of Clinical Chemistry. Tietz, N.W(Ed) Chap., 10: 512-514.

16-Snedecor, G.W. and Cochran, W.G. (1973). Statistical Methods. $6^{\text {th }}$ the Iowa state University press., 238-248.

17-Schaalan, M. ; El-Abhar, H.S.; Barakat, M.and ElDenshary, E.S.( 2009). Westernized-like-diet-fed rats: effect on glucose homeostasis, lipid profile, and adipocyte hormones and their modulation by rosiglitazone and glimepiride. J Diabetes Complications.,23:199-208.

18-Oluyemi, K. A.;Omotuy, I. O.; Jimoh, O. R.; Adesanya, O. A.; Saalu, C. L. and Josiah, S. J. (2007). Erythropoietic and anti-obesity effects of Garcinia Cambogia (bitter Kole) inwistar rats. Biotechnol Appl. Biochem., 46: 69-72.

19-Huang, H. L.; Hong, Y. W.; Wong, Y. H.; Chon, Y. N.; Chyvan, J. H.; Huang, C. I. and Chao, P. M. (2008). Bitter melon (Momordica charantia L.) inhibition adipocyte hypertrophy and down regulates lipogenic gene expression in adipose tissue of diet-induced obese rats. Br. J. Nutr., 99: 230-239.

20-Kim, S. J.; Jung, J. Y.; Kim, H. W. and Park, T. (2008). Anti-obesity effects of Juniperus chinesis extract are associated with increased AMPactivated protein kinase expression and phosphorylation in the visceral adipose tissue of rats. Boil. Pharm. Bull., 31:1415-1421.

21-Goyal, R. K. and Kadnur, S. V. (2006). Beneficial effects of zingiber officinale on goldthioglucose induced obesity. Fitoterapia., 77: $160-163$.

22-Han, L. K.; Nose, R.; Li, W.; Gong, X. J.; Zheng, Y. N.; Yoshikawa, M.; Koike, K.; Nikaido, T.; Okuda, H. and Kimura, Y. (2006). Reduction of fat storage in mice fed a high fat diet long term by treatment with saponins prepared from kochia scoparia fruit. Phytother Res., 20: 877-882.

23-Raju, J.; Gupta, D.; Rao, A.R.; Yadava, P.K.and Baquer, N.Z. (2001).Trigonella foenum graecum (fenugreek) seed powder improves glucose homeostasis in alloxan diabetic rat tissues by reserving the altered glycolytic, gluconeogenic and lipogenic enzymes.Mol Cell Biochem.,224:45-51.

24-Singh, D.; Chander, V. and Chopra, K.( 2004). Protective effect of naringin, a bioflavonoid on ferric nitrilotriacetate-induced oxidative renal damage in rat kidney.Toxicology., 201:1-8.

25-Gold, A.H.( 1970). The effect of diabetes and insulin on liver glycogen synthetase activation. J Biol Chem.,245:903-905. 